Ixterstital Phosphate as Phosphate Phosphorts in Parts per Million of Dry Mud and Adsorbed Phosphate Similarly in Dry Silt FROM MUD SAMPLES NEAR CALICUT

\begin{tabular}{|c|c|c|c|c|c|c|c|c|c|}
\hline \multirow{3}{*}{ Months } & \multirow{3}{*}{$\begin{array}{l}\text { Samples } \\
\text { per } \\
\text { station }\end{array}$} & \multicolumn{4}{|c|}{ Station I (4 m.) } & \multicolumn{4}{|c|}{ Station II $(19 \mathrm{~m})}$. \\
\hline & & \multicolumn{2}{|c|}{ Interstitial } & \multicolumn{2}{|c|}{ Adsorbed } & \multicolumn{2}{|c|}{ Interstitial } & \multicolumn{2}{|c|}{ Adsorbed } \\
\hline & & Range & Jean & Range & Mean & Range & Mean & Range & Mean \\
\hline $\begin{array}{l}\text { January } \\
\text { February } \\
\text { March } \\
\text { April } \\
\text { May } \\
\text { June }\end{array}$ & $\begin{array}{l}5 \\
4 \\
3 \\
4 \\
3 \\
2\end{array}$ & $\begin{array}{r}13 \text { to } 35 \\
22 \text { to } 43 \\
19 \text { to } 27 \\
11 \text { to } 25 \\
13 \text { to } 19 \\
7 \text { to } 20\end{array}$ & $\begin{array}{l}26 \\
35 \\
23 \\
17 \\
15 \\
13\end{array}$ & $\begin{array}{r}19 \text { to } 80 \\
9 \text { to } 41 \\
13 \text { to } 43 \\
17 \text { to } 28 \\
20 \text { to } 35 \\
22 \text { to } 25\end{array}$ & $\begin{array}{l}47 \\
21 \\
25 \\
24 \\
27 \\
23\end{array}$ & $\begin{array}{c}21 \text { to } 27 \\
25 \text { to } 33 \\
17 \text { to } 25 \\
12 \text { to } 19 \\
24 \text { to } 46 \\
9\end{array}$ & $\begin{array}{r}25 \\
29 \\
20 \\
15 \\
33 \\
9\end{array}$ & $\begin{array}{r}18 \text { to } 68 \\
9 \text { to } 22 \\
16 \text { to } 39 \\
9 \text { to } 33 \\
12 \text { to } 17 \\
4 \text { to } 16\end{array}$ & $\begin{array}{l}33 \\
16 \\
24 \\
18 \\
14 \\
10\end{array}$ \\
\hline
\end{tabular}

the pre-monsoon months in 1952 again, the phosphate content of the inshore water was very low, but it increased after the commencement of the monsoon rough weather that disturbed the mudbanks. It appears highly probable that the well-marked seasonal features in the biology of the inshore area along this coast are closely related among other factors to the existence of these extensive mudbanks, the retention by them of relatively large quantities of phosphates (and perhaps other nutrients) and the release of these during the south-west monsoon every year.

The mudbanks have also been found to contain fairly high quantities of adsorbed phosphate. The material of these mudbanks is derived partly from the laterite formation which fringes this coast ${ }^{5}$. An analysis of a sample of laterite has revealed a high 'adsorbed' phosphate content, and since a considerable quantity of laterite silt is washed into the sea during the rainy seasons, this seems to be a constant source to supplement the local turnover of phosphates in the inshore area.

I wish to thank Dr. N. K. Panikkar, Dr. W. R. G. Atkins and Dr. B. S. Bhimachar for helpful criticism.

Central Marine Fisheries Research Sub-Station, West Hill, Calicut, India. Aug. 30.

1 Vortimer, C. H., J. Ecol., 29, 280 (1941); 30, 147 (1942).

"Moore, H. B., J. Mar. Biol. Assoc. U.K., N.S., 16, (2), 595 (1930); 17, (2), 325 (1931).

${ }^{3}$ Stephenson, W., J. Mar. Biol. Assoc. U.K., N.S., 28, (2), 371 (1949); Proc. Indo-Pacific Fish. Coun., 2nd Meeting 1950, 184 (1951) +hochford, D. J., Proc. Indo-Pacific Fish. Coun., 2nd Meeting 1950,
157 (1951),; Aust. J. Mar. Freshuater Res., 2, (1), 1 (1 951).

"Iristow, R. C" "History of Mudbanks" (Cochin Govt. Press, 1938). Du cane, $C$. G., Bristow, R. C.. Coggin Brown, $C_{\text {.. }}$ and Keen, B. A., Report of the Specia

\section{Occurrence of Puccinia polysora Underw. in East Africa}

Rhind, Waterston and Deighton reported epidemics of Puccinia polysora Underw. in West Africa in 1949 and the following years ${ }^{1}$. Fears were exprossed that this disease might eventually reach East Africa. Plans were accordingly made for authorities in West Africa to test East African varieties of maize for susceptibility to the fungus, and for the introduction of maize varieties from Central America in the hope that resistant types might be found in an area where the disease is endemic.

The maize rust hitherto recorded in East Africa and generally present throughout the Territories is Puccinia sorghi Schw. In June 1952, outbreaks of maize rust, exceeding in severity any previous occurrence, appeared in the Coast Province of Kenya. Collections, which comprised the uredo and teleuto stages, were examined by Dr. G. R. Bisby ${ }^{2}$, who stated that the teleuto stage agreed exactly with the original American collections, thus affording final confirmation of an identification which remained uncertain so long as the uredo spores alone were available. This is believed to be the first record of the teleuto stage of $P$. polysora outside America.

Subsequent collections of uredo material were examined from Zanzibar and milder attacks from Uganda and Tanganyika, where both species of rust were found occupying the same leaf. All collections from the Kenya Highland have, so far, been $P$. sorghi; and, in fact, all records of severe attacks of $P$. polysora have been from the warmer, more humid areas. It is hoped that the Kenya Highlands, where maize is the most important food crop of the native population, may remain free.

Department of Agriculture,

R. M. Nattrass

\section{Nairobi.}

Sept. 26.

${ }^{1}$ Rhind, J., Waterston, J. M., and Deighton, F. C., Nature, 169, 631 (1952)

${ }^{2}$ Bisby, G. R., in litt.

\section{Cerastium arcticum Lange}

RECENT publications containing references to this plant have used the name $C$. edmondstonii (Wats.) Murb. and Ost. ${ }^{1}$ in preference to the older name C. arcticum Lange ${ }^{2}$. 'The objection to using the older name is, according to Hylander", that "there is no authentic, i.e. chosen by Lange, type specimen". But this in itself is no reason for dismissing the older name since the description is validly published. Moreover, Murbeck and Osterfeld in their description ${ }^{1}$ only redescribed Lange's plant. They also took the varietal epithet, var. edmondstonii, and gave it specific rank. 'This is in contradiction to the rules of botanical nomenclature, and therefore the name C. edmondstonii is illegitimate.

Recent work on the cytology of this species, using material collected from Snowdon in Wales and Ben Nevis in Scotland, has shown that the ehromosome number is $2 n=108$ (Fig. 1). Some seedlings, however, gave higher chromosome numbers, and it is suspected that occasionally this species may be cross-pollinated by $C$. holosteoides Fries (C. vulgatum L.), $2 n=144$, which grows in the vicinity. One plant, from Snowdon, showed a highly irregular meiosis with many lagging chromosomes at both first and second anaphase, and it is thought that this may have been a hybrid, although it closely resembled $C$. arcticum. Pollen-mother cells from other plants showed a perfectly regular meiosis with $n=54$. At first metaphase many multivalents can be seen (Fig. 2), usually in the centre of the cell with the bivalents arranged in a ring outside them. A very similar arrangement has been seen in $C$. holosteoides. 